ITP

35,8

52

Received 17 March 2021

Revised 6 September 2021 Accepted 26 September 2021

\section{Personality in information systems professions: identifying archetypal professions with suitable traits and candidates' ability to fake-good these traits}

\author{
Luka Tomat, Peter Trkman and Anton Manfreda \\ Academic Unit for Business Informatics and Logistics, \\ School of Economics and Business, University of Ljubljana, Ljubljana, Slovenia
}

\begin{abstract}
Purpose - The importance of information systems (IS) professions is increasing. As personality-job fit theory claims, employees must have suitable personality traits for particular IS professions. However, candidates can try to fake-good on personality tests towards the desired personality type. Thus, the purpose of this study is to identify archetypal IS professions, their associated personality types and examine the reliability of the Myers-Briggs Type Indicator (MBTI) personality test in IS recruitment decisions.

Design/methodology/approach - The authors reviewed academic literature related to IS professions to identify job archetypes and personality traits for IS professions. Then, the authors conducted an experiment with 452 participants to investigate whether candidates can fake-good on personality tests when being tested for a particular IS profession.

Findings - The identified job archetypes were IS project manager, IS marketing specialist, IS consultant, IS security specialist, data scientist and business process analyst. The experimental results show that the participants were not able to fake-good considerably regarding their personality traits for a particular archetype.

Research limitations/implications - The taxonomy of IS professions should be validated further. The experiment was executed in an educational organisation and not in a real-life environment. Actual work performance was not measured.

Practical implications - This study enables a better identification of suitable candidates for a particular IS profession. Personality tests are good indicators of the candidate's true personality type but must be properly interpreted.
\end{abstract}

Originality/value - This study enhances the existing body of knowledge on IS professions' archetypes, proposes suitable MBTI personality types for each profession and provides experimental support for the appropriateness of using personality tests to identify potentially suitable candidates.

Keywords Information systems professions, Personality traits, MBTI personality test, Answer reliability, Experiment

Paper type Research paper

\section{Introduction}

Digital transformation, especially nowadays coupled with COVID-19, has increased the

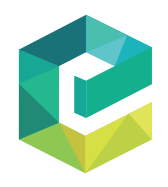

demand for enterprises' digitalisation and consequently the number of information systems

Information Technology \& People Vol. 35 No. 8, 2022 pp. $52-73$

Emerald Publishing Limited 0959-3845

DOI 10.1108/ITP-03-2021-0212
(C) Luka Tomat, Peter Trkman and Anton Manfreda. Published by Emerald Publishing Limited. This article is published under the Creative Commons Attribution (CC BY 4.0) licence. Anyone may reproduce, distribute, translate and create derivative works of this article (for both commercial and noncommercial purposes), subject to full attribution to the original publication and authors. The full terms of this licence may be seen at http://creativecommons.org/licences/by/4.0/legalcode

The authors acknowledge the financial support of the Research Agency of Slovenia (grant no. J5-9329). 
(“IS”) professionals (Baller et al., 2016; Tomat and Trkman, 2019; Seetharaman, 2020). The pace of technological change has accelerated growth in the available IS jobs (Moreno et al., 2012; Bessen, 2019; World Economic Forum, 2020). Thus, companies need more IS professionals to work with all other employees in driving the digital transformation (DaSilva and Trkman, 2014; Jia et al., 2018; Manfreda and Indihar Stemberger, 2019). The professions at the intersection of technology, business and organisational aspects, termed the "IS profession" (see also Yagmur and Jaideep, 2018; Abubakre et al., 2020), are rising in importance. Consequently, appropriately identifying individuals who can be trained to work in those jobs is a major challenge for companies, education/training providers, individuals and society (Kitch and Yasnoff, 2003).

The number of employees in the IS professions is increasing (Rainie and Anderson, 2017), and finding talented employees for these professions is amongst the most worrisome tasks for IS managers (Kappelman et al., 2019). The number of candidates wishing to pursue IS professions has also surged; however, those jobs require specific personality traits (Sackett and Walmsley, 2014). As personality-job fit theory stipulates, people need to have appropriate personality traits for a particular profession. An individual's personality changes less frequently than do their job-related skills or requirements (Koong et al., 2002; Mroczek and Spiro, 2003; Roberts and Mroczek, 2008). Moreover, without a proper match of personality traits and professions, a huge risk is that individuals will be attracted solely by the job's lucrativeness (Sorauren, 2000).

The IS field includes many kinds of professions (Kim et al., 2006) that each requires different personality traits. In line with personality-job fit theory, it is important to align work tasks with employees' capacities that arise from their personality traits (Capretz and Ahmed, 2010). Given the above, employees require a specific personality type to perform different professions successfully. Thus, there is a need for a classification system of IS professions that would also contain a set of personality traits for a particular profession. Against this background, the crucial question is whether IS profession archetypes exist that are consistent over time. To operationalise such a classification scheme, each individual's personality must be identified with various personality tests (Morgeson et al., 2007a).

However, if candidates know that the test results will have affect the employment decision, they may give false answers to show a better match to the desired personality profile (Dalen et al., 2001; Rees and Metcalfe, 2003). Although the appropriateness of personality testing has been questioned in general (Morgeson et al., 2007b), its usefulness for identifying true personality traits in such a situation must be studied even more carefully.

Given the above, two research questions arise: (1) Which personality traits and skills are required for each typical IS profession? (2) To what extent can individuals fake-good tests to show they possess the personality traits required for a particular profession?

To answer these questions, we analysed the literature to propose a classification of IS job archetypes with their associated personality traits. Afterwards, we used the MyersBriggs Type Indicator (MBTI) personality test on a sample of 452 undergraduate students. We performed a parametric $t$-test for independent samples to analyse the extent to which the participants adjusted their answers to reflect better the sought-after personality traits. We show that the MBTI personality test mostly measured the respondents' personalities properly. Moreover, participants who were more interested in a specific profession were unable to significantly fake-good on their personality traits.

This paper is structured as follows: First, we present the importance of personality for IS professionals. Then, we explain why IS professions must be classified. Next, we explain the importance of personalities and their measurement in IS professions and provide the
Personality in IS professions 
ITP

35,8

classification for IS profession archetypes along with the matching personality traits. The Methodology section describes the experiment. Results with analysis are provided afterwards. The last section provides a discussion of the results and final remarks, along with the study's limitations and further research possibilities.

\section{Importance of personality for information systems professionals}

Individuals' personalities are one of the most important factors for workplace performance (Barrick, 2005; Maier, 2012; Wynekoop and Walz, 2000; Abubakre et al., 2020) and individuals' career development (Katic et al., 2018; Zimmerman, 2008). The personality-job fit and related theories have widely acknowledged that people flourish in their work environments when there is a good fit between their personality type and the tasks they need to perform (Williamson et al., 2013). Personality-job fit focusses explicitly on the match between job requirements and the individual. It has unique effects on work beyond the person-organisation fit (Erdogan and Bauer, 2005). Personality is associated with much work-related behaviour and predicts job performance across a wide variety of outcomes in jobs ranging from semi-skilled to executives (Barrick, 2005). Personality-job fit effect is even stronger in knowledge-intensive positions (Sekiguchi and Huber, 2011). This is also the case for IS professions where the jobs' complexity brings a strong positive relationship between personality and performance (Le et al., 2011). According to a meta-analysis in Zimmerman (2008), personality-job fit also has an effect on job behaviour and turnover intentions. Empirical and theoretical understanding of the nature of the relation between personality and job types is thus crucial (Barrick, 2005). Therefore, companies should seek desired personalities when recruiting new personnel (Barrick et al., 2001).

Because organisations nowadays are requiring more IS professionals, there is a gap between the companies' demand and labour market supply (Eberhard et al., 2017). Hence, a key challenge is to select a pool of suitable applicants. This is further amplified by the quickly changing requirements (Benešová and Tupa, 2017). Furthermore, the skills gap between what the market offers and what the industry demands constantly is high (Jackson, 2010; Malik and Venkatraman, 2017). The skills needed for specific sub-professions emerging with the appearance of new technologies and concepts (such as the digital transformation, Internet of Things and artificial intelligence) are constantly changing (Litecky et al., 2009) and should be developed continuously by employees. The personal characteristics needed for archetypal IS professions are more stable over time.

Therefore, the personality traits required for particular IS professions should be studied thoroughly. One of the most profound studies in the IS area, by Devaraj et al. (2008), emphasised the need for a richer consideration of the influence of personality in IS research. Several studies cover the theoretical aspects of personality's importance for job performance in general (Hurtz and Donovan, 2000), and some have specifically tackled the personality traits amongst the IS professions (Lounsbury et al., 2009).

Personality can be measured by various personality tests. Different methods exist to determine personality traits. One of the first approaches to measure personality traits was the Minnesota Multiphasic Personality Inventory. The Sixteen Personality Factor (16PF) Questionnaire is used to identify the appropriate personality traits when selecting job candidates (Cattell and Mead, 2008). The 16PF test paved the way for the "Big Five" personality test, also known as the five-factor model, with a person's traits of openness, conscientiousness, extraversion, agreeableness and neuroticism (Hurtz and Donovan, 2000). Another measure for personality traits is the Comrey Personality Scales, which defines an individual's personality based on eight dimensions (Rushton and Irwing, 2009).

However, one of the most widely used metrics to measure personality traits is the MBTI, which is immensely popular and has had impressive longevity, spanning over 70 years. Over 
two million people a year officially take the MBTI, including employees in 89 of the Fortune 100 companies (Stein and Swan, 2019). The MBTI is considered an easy-to-use personality tool and can be utilised for various purposes (Sadler, 2015). It is most popular for categorising personalities to fit specific professions (Furnham, 1996) and hence is used most broadly in hiring decisions (Rushton et al., 2007). Varona et al. (2012) analysed studies on personalities and found that the adequacy of MBTI personality types for software engineers has been changing in the last years, primarily due to the complexity of ever-evolving software development processes, which demand new skills that are related to other personality types. Hence, the extents of personality types for specific IS professions are changing, allowing for employees to be more efficient and productive.

In addition to the extensive use of the MBTI to support hiring decisions, the test has also been researched thoroughly within the IS area (Kruck et al., 2014). Lesiuk et al. (2009) examined professional computer IS developers and used the MBTI to measure the incidence of basic personality types. Their study revealed a significant prevalence of introversion, thinking and judging types. Next, Capretz and Ahmed (2010) determined the personality traits based on the MBTI that were most suitable for performing various work tasks within the software-developer profession in each of the software-development phases. They showed that employees' key characteristics are extraversion and sensing in the system analysis phase; intuition and thinking in the planning phase; introversion, thinking and perceiving in the programming phase; sensing and judgement in the testing phase and sensing and perception in the maintenance phase.

Similarly, Varona et al. (2011) used the MBTI to identify software developers' personality traits and showed that the most pronounced personality type of an employee was a combination of extraversion, sensing, thinking and judgement. Cruz et al. (2015) analysed more than 90 papers on personality in software engineering published between 1975 and 2010 and showed that MBTI had been the most widely used measures to test personality. Capretz et al. (2015) researched MBTI personality traits representation of software developers (system analysts, software designers, programmers, software testers and software maintainers) and showed the importance of matching the right people to specific roles in software engineering. Considering specific traits, most software developers are more extroverted than introverted, have more sensing than intuition, more thinking than feeling and more judging than perceiving. Accordingly, Gilal et al. (2017) measured the relationship between different personality types for software programmers and suggested that each personality type had its behaviour, which the employer needed to consider carefully when making hiring decisions.

\section{Classification of the information systems professions}

Given the importance of the fit between personality and job tasks in general, and in the IS field in particular, and the growing need for IS professionals, there is a necessity for developing a classification of archetype IS professions along with identifying the required personalities.

Previous literature reviews offered some classifications of IS professions. Todd et al. (1995) proposed one of the earliest classifications of IS professions based on a content analysis of IS job advertisements and classified the IS professions as programmers, system analysts and managers. For each type, they provided a job description and desired technical, business and system knowledge. Furthermore, Warhurst et al. (2006) proposed classifying IS professions into three groups: IS design and development (IS strategy planning, professionals and software professionals), IS operations (IS operations and user support technicians) and IS users (database clerks, telephone salespeople and call centre agents). Next, Aasheim et al. (2009) identified seven areas of IS professions: office work (e.g. data entry), databases, user support, programming, network technologies, IS design and analysis and Web application 
ITP

35,8

design and development. Furthermore, Aken et al. (2009) classified IS professions into six groups: web developers, software developers, database developers, managers and project analysts. In addition to academia, the practice also offers some classification methods for IS professions. Research and Markets (2019), the world's largest market research company, classifies IS jobs into five categories: manager jobs, professional jobs, IS technical jobs, blockchain jobs and IT support.

Employees need appropriate skills for their specific profession. Two of the first classification schemes for skills in IS professions were published in the 1980s (Nunamaker et al., 1982; Cheney et al., 1989), and the number of studies on this topic has increased since. Todd et al. (1995) provided a classification of professions based on technical knowledge, business knowledge and IS knowledge and suggested several skills for each category. Noll and Wilkins (2002) identified a general set of skills employees needed and divided IS professions into five key areas: business knowledge, advanced IS and applications, programming, analytics and customer support. Furthermore, Litecky et al. (2009) discovered that employees in IS professions must have a variety of skills, which can be combined into business skills, soft skills, general technical skills, programming and databases and system administration. Additionally, De Mauro et al. (2018) classified big data job roles and related skills into nine homogeneous groups, namely cloud, coding, database management, architecture, project management, systems management, distributed computing, analytics and business impact skills. To perform a certain profession successfully, employees must develop their skills constantly because these are some of the most important factors for fostering innovation, productivity and competitiveness. In addition, appropriate skills stimulate employees' motivation to perform their work (Garg and Rastogi, 2006). Studies began to suggest that employees' nontechnical skills in IS professions were more important for employers than were their technical skills (Young, 1996; Richards et al., 1998; Van Slyke et al., 1998).

As shown, the necessary generic skills have been relatively stable over the decades. Obviously, employees should develop specific knowledge and skills (e.g. new tools, methodologies or technologies) throughout their careers (Rae, 2005). However, one's personality traits cannot be easily changed (Roberts and Mroczek, 2008). Because employees with the proper personality types likely will be more able to develop required skills continually, personality aspects must be considered in the recruitment process. Importantly, Persaud (2020) discovered that organisations tend to consider personality traits when recruiting personnel in data analytics, computing and business-related jobs. As Burton et al. (2016) showed, organisations are also aware of the importance of hiring candidates with the appropriate personality traits because employees with the right personalities tend to have longstanding career success. Organisations must allocate their employees to specific jobs in line with their personality traits (Da Cunha and Greathead, 2007). The literature offers several studies that investigate the personality traits needed for specific IS professions. Lounsbury et al. (2007) examined personality traits related to IS jobs and career satisfaction. Building on the big five-related traits, they found that assertiveness, emotional resilience, extraversion, openness, teamwork disposition, customer service orientation, optimism and work drive were the most important traits in the IS field. Another interesting study, by Guillemette and Paré (2012), proposed five ideal profiles: partner (tackles business transformation and innovation), systems provider (tackles systems that support the organisation's needs), architecture builder (reduces architecture complexity to gain business agility), technological leader (tackles IS-related strategic opportunities) and project coordinator (business-related strategic opportunities).

As seen from the above, different personality trait categories exist, and various combinations of characteristics or personal attributes can be used to define an individual's personality. For the purposes of this research, we chose the MBTI test because it is the most 
commonly used approach for identifying personality traits and supporting recruitment processes (Livingood, 2003; Capretz and Ahmed, 2010; Maier, 2012; Capretz et al., 2015; Furnham, 2017). It is considered consistent and reliable and provides the observer with helpful information about the respondent's personality traits (Capraro and Capraro, 2002; Kennedy and Kennedy, 2004). It consists of items that comprehensively measure its scales (Tischler, 1994). The MBTI matches the respondent's personality with one trait for each of the four bipolar categories: extraversion (E)-introversion (I), sensing (S)-intuition $(\mathrm{N})$, thinking $(\mathrm{T})$-feeling $(\mathrm{F})$ and judging $(\mathrm{J})$-perceiving $(\mathrm{P})$. Sixteen personality types can result from the combinations of the traits in these four categories: INFJ, INFP, ENFJ, ENFP, INTJ, INTP, ENTJ, ENTP, ISTJ, ISFJ, ESTJ, ESFJ, ISTP, ISFP, ESTP and ESFP.

Based on an in-depth critical review of scholarly literature from the areas of IS professions, skills and personality-trait classification methods; on thorough consideration of the MBTI personality types and on consultations with experts from the field to understand the relationships amongst personality types and IS professions, we propose archetypal IS professions along with the associated MBTI personality types, as shown in Table 1. Each of the proposed professions is attached to a unique personality type that matches the specific profession's identified characteristics along with a specific MBTI personality type. The set of characteristics that reflect the specific IS archetype were extracted from the literature (Kriegsman and Barletta, 1993; Todd et al., 1995; Marcella and Middleton, 1996; Wynekoop and Walz, 2000; Denning, 2001; Cappel, 2002; Noll and Wilkins, 2002; Kim et al., 2006; Lounsbury et al., 2007; Devaraj et al., 2008; Lee and Han, 2008; Aken et al., 2009; Litecky et al., 2009; Capretz and Ahmed, 2010; Varona et al., 2011; Aasheim et al., 2012; Davenport and Patil, 2012; Guillemette and Paré, 2012; Maier, 2012; Cohen et al., 2013; Summers et al., 2013; Van der Aalst, 2014; Flynn and Philbin, 2014; Kruck et al., 2014; Sackett and Walmsley, 2014; Müller et al., 2016; Pflügler et al., 2018; Mendes et al., 2019; Persaud, 2020). Then, each author assessed each characteristic individually. Based on these assessments, the final characteristics for the specific professions were defined. Next, we identified the personality type for each profession. For each category, the MBTI personality trait that occurred the most often in the analysed literature was selected for each profile. The combination of those four traits was used to define the personality type.

The importance of personality raises the question of how to measure an individual's personality traits impartially. Candidates may try to give insincere answers to get closer to the desired personality profile (Dalen et al., 2001). Given the above, we used the MBTI to study the extent to which individuals can mislead the tests by faking good to indicate that they possess the personality traits required for a particular profession.

Although several studies have shown that candidates do try to fake-good on personality questionnaires during recruitment processes (Martin et al., 2002; Rees and Metcalfe, 2003), the resilience of the MBTI against candidates faking their personality traits remains underresearched. Although some studies have investigated attempts to fake answers on MBTI tests to influence hiring decisions (Mahar et al., 1995, 2006), research tackling this phenomenon in IS professions is lacking. Thus, we must study how reliable the MBTI is for measuring personality traits when candidates know that the test's purpose is to find a suitable candidate for a particular job.

\section{Methodology}

In our experiment, we examined the MBTI personality test's reliability for the aboveidentified IS professions. Study participants were business students from a triple-crown accredited business school. This sample was chosen because students represent a population entering the labour market and thus constitute a good proxy for junior employees regarding 


\begin{tabular}{lll}
\hline IS profession & Description & Needed characteristics
\end{tabular}

IS project manager Takes care of planning IS and integrating the plan - Ingenuity

\section{8} (ENTJ)

into business while following business goals. Plans, implements and monitors IS projects and prepares IS policies (e.g. security and privacy policies)

IS marketing specialist (ENTP)

IS consultant (ENFP)

IS security specialist (ISTJ)

Data scientist (INTP)

Business process analyst (INTJ) suggests possible improvements. Coordinates
Collects and processes data and performs statistical analyses to obtain new information and knowledge from a large amount of data to help achieve business goals

Understands the business needs and goals of the clients' organisation and prepares strategic proposals for clients on how to use IS in their companies. Participates in designing IS in terms of functionality and architecture. Plans, implements, test, and monitors IS and trains users to use the IS.

Ensures the continuous and secure operation of IS, computer networks, cloud technologies and mobile devices. Provides data security measures. Prepares and implements security policies and security solutions to prevent malfeasance involving data by unauthorised persons. Plans and conducts penetration tests
- Determined leadership

- Logical thinking

- Rational thinking

- Ability to make analytical assessments

- Drawing energy from the environment

- Solving challenges and

problems

- Ingenuity

- Creativity

- Drawing energy from the environment

- Good analytical properties

- Logical thinking

- Ability to quickly find the right solutions to problems

- Communicativeness

- Establishing contact with people

- Intuition

- Commitment

- Subjectivity

- Thoughtfulness

- Critical thinking

- Determination

- Ability to detect changes in the environment

- Detail orientation

- Ability to plan

- Organisational skills

- Drawing energy from their inner world

- Calmness

- Prioritising acting over speaking

- Intuition

- Ingenuity

- Ability to assess the situation objectively

- Drawing energy from their inner world

Analyses business processes and workflows and between process owners and the IS department. Provides business users with the knowledge necessary for successful business process management
- Organisational skills

- Originality

- Planning capabilities

- Critical thinking

- Determination

- Independence

- Analytical skills

- Drawing energy from their inner world
Table 1.

IS profession archetypes
*E: Extraversion
I: Introversion

\begin{abstract}
S: Sensing
\end{abstract}
$N$ : Intuition

T: Thinking
F: Feeling

\section{J: Judging} P: Perceiving 
personality and knowledge (Erjavec et al., 2019). Besides, because they are at an early career stage, their personality is a determining factor for recruitment (Trkman et al., 2019; Compeau et al., 2012). Contrarily, for senior employees, their CVs and employment records can be a much better indicator of their suitability for a particular type of job than administered tests. Moreover, student samples are more homogenous than nonstudent samples, creating a bigger effect size and lower error variance (Blut and Wang, 2019), while in similar experiments, there are no significant difference between student and nonstudent samples (Barari et al., 2020). Homogeneous samples with students with a similar academic background are often used in such research (Swope et al., 2008). The fact that students knew their answers would not affect their academic record further reduces the possibility of a bias (Salleh et al., 2014).

The experiment occurred on the business school's premises in May 2019 during an ISrelated class. All students enrolled in the study programme were invited for voluntary participation and were randomly divided into different groups. We prepared a different scenario for the control and the treatment group. Participants in the treatment group were further randomly divided into separate groups.

We introduced participants in the treatment group to various IS professions that required the desired personality traits. For each group, one IS profession was randomly selected. The experiment leader provided participants with oral instructions and presented the profession's characteristics and the potential employer looking to hire students for the selected job. Participants were unaware that their participation was only part of the research experiment and not a real job offer. Besides, they were misleadingly told that the names of matching participants would be sent to potential employers seeking entry-level candidates at the considered business school.

On the other hand, the control group was instructed merely to complete the questionnaire without a stated purpose. The purpose of having both the treatment groups and the control group was to examine how much the candidates for various IS professions adjusted their answers for a test that determined personality traits. A total of 452 students participated in the experiment, with 301 participants in the treatment group and 151 participants in the control group. Of the respondents, $62 \%$ were female, and $38 \%$ were male.

All students received a paper questionnaire of the MBTI personality test. The MBTI personality test comprised 70 questions, with only two possible answers for each question ("a" or "b"). According to the MBTI, the predominant answers to a particular set of questions form a personality trait. Thus, the final grade is a sequence of four letters representing a personality trait, namely "E/I," "S/N," "T/F" and "J/P." If "a" answers predominate each individual set, the result is labelled as the first letter from the pair listed above and vice versa. In our analysis, we used numerical values, replacing "a" answers with the number 1 and " $b$ " answers with 2 . Consequently, values between 1 and 1.5 represented the first letter in the personality traits, signifying that more "a" answers were selected compared to "b" answers. Values between 1.5 and 2 represented the second letter in each pair of personality traits. The questionnaire also included questions regarding interest in the selected IS profession and the desire to continue the career in the assigned profession. These questions were used to additionally examine the extent of adjusting the answers to fake-good individual personality traits and to better match oneself with the profession's characteristics the potential employer would be looking for.

Table 2 presents the number of participants for each surveyed profession in the treatment group. Group numbers were not equal, partly due to the institution's educational orientation where the experiment occurred and partly due to the different sizes of students' classes and voluntarily participation. 
ITP

35,8

60

\section{Results}

We analysed the data via SPSS software and parametric $t$-tests for independent samples. We compared each treatment group's results with the control group's results. We also compared differences for participants who explicitly expressed their desire to continue a career in the selected profession.

First, we performed the analysis with all participants. Although differences appeared in answers from the control group and each profession, not all differences were statistically significant. Table 3 presents three IS professions with no statistically significant differences in personality traits, namely IS security specialist, data scientist and IS marketing specialist. However, Table 4 presents professions (business process analyst, IS project manager, data scientist and IS consultant) where statistically significant differences appeared in at least one personality trait.

As evident from Table 4, statistically significant differences appear on personality traits for the business process analyst and IS project manager professions and on three personality traits for the IS consultant profession. One difference, although not the largest, is just large enough to cause a change in the personality trait for IT consultant, namely from "T" to "F."

The direction to which participants adjust their answers is crucial, so we compared each group's personality trait with the proposed personality traits for an IS profession (see Table 1). The arrows in Figures 1 and 2 indicate differences between the control group and the selected group. Arrows may thus indicate that participants intentionally tried falsifying their real personality traits to suit the desired profession better. In these cases, participants differed from the control group and answered in the direction that would fit the chosen profession. In both figures, circles represent cases where participants did not adjust their answers in the direction that would fit the chosen profession. This may indicate they did not intend to fake their personality, thus we cannot conclude that participants tailored their actual personality traits to the chosen profession.

To realistically analyse deceptive answers to fit the desired profession, we also performed an additional analysis on participants who expressed higher interest in starting their career in the chosen profession only. In the additional analysis, only participants who explicitly indicated they had a clear interest in the selected profession and would like to continue their career in it were included. Although several differences increased, some were not statistically significant due to the smaller sample in this case (Table 5). This is evident when comparing responses between the control group and the IS security specialist group, where participants apparently adjusted their answers towards the profession's proposed personality trait. The differences were large enough to change the IS security specialist's personality trait from "E" to "I." However, these differences are not statistically significant.

Table 6 includes professions with statistically significant differences in at least one personality trait. No statistically significant differences for the data scientist profession appeared when considering all participants. However, considering only participants with a higher interest revealed a statistically significant difference for one personality trait. A statistically significant difference for one personality trait was also identified for business

Number of participants

IS project manager

Table 2.

IS consultant 


\begin{tabular}{|c|c|c|c|c|c|c|c|c|}
\hline \multirow[b]{2}{*}{ Variable } & \multirow[b]{2}{*}{ Profession } & \multirow[b]{2}{*}{$N$} & \multirow[b]{2}{*}{ Mean } & \multirow[b]{2}{*}{ Std. dev. } & \multirow[b]{2}{*}{ Sig. } & \multicolumn{2}{|c|}{ Personality traits (MBTI) } & \multirow{2}{*}{$\begin{array}{l}\text { Personality in } \\
\text { IS professions }\end{array}$} \\
\hline & & & & & & Control & Selected profession & \\
\hline \multirow{4}{*}{ E_I } & Control & 151 & 1.42 & 0.254 & & $\mathrm{E}$ & & \\
\hline & IS security specialist & 15 & 1.48 & 0.317 & 0.359 & & $\mathrm{E}$ & \\
\hline & Data scientist & 58 & 1.44 & 0.285 & 0.500 & & $\mathrm{E}$ & \\
\hline & IS marketing specialist & 52 & 1.39 & 0.273 & 0.599 & & $\mathrm{E}$ & \\
\hline \multirow[t]{4}{*}{ S_N } & Control & 151 & 1.39 & 0.166 & & $\mathrm{~S}$ & & 61 \\
\hline & IS security specialist & 15 & 1.31 & 0.151 & 0.094 & & $\mathrm{~S}$ & \\
\hline & Data scientist & 58 & 1.35 & 0.170 & 0.205 & & $\mathrm{~S}$ & \\
\hline & IT marketing specialist & 52 & 1.38 & 0.168 & 0.736 & & $\mathrm{~S}$ & \\
\hline \multirow[t]{4}{*}{ T_F } & Control & 151 & 1.46 & 0.180 & & $\mathrm{~T}$ & & \\
\hline & IS security specialist & 15 & 1.38 & 0.186 & 0.122 & & $\mathrm{~T}$ & \\
\hline & Data scientist & 58 & 1.47 & 0.198 & 0.546 & & $\mathrm{~T}$ & \\
\hline & IS marketing specialist & 52 & 1.48 & 0.187 & 0.332 & & $\mathrm{~T}$ & Average values of the \\
\hline \multirow[t]{4}{*}{ J_P } & Control & 151 & 1.35 & 0.154 & & $\mathrm{~J}$ & & control group and \\
\hline & IS security specialist & 15 & 1.32 & 0.136 & 0.455 & & $\mathrm{~J}$ & treatment groups (with \\
\hline & Data scientist & 58 & 1.34 & 0.136 & 0.499 & & $\mathrm{~J}$ & no significant \\
\hline & IS marketing specialist & 52 & 1.37 & 0.161 & 0.463 & & J & differences) \\
\hline
\end{tabular}

\begin{tabular}{|c|c|c|c|c|c|c|c|c|}
\hline Variable & Profession & $N$ & Mean & Std. dev. & Sig. & $\begin{array}{l}\text { Personali } \\
\text { Control }\end{array}$ & $\begin{array}{l}\text { ty traits (MBTI) } \\
\text { Selected profession }\end{array}$ & \\
\hline \multirow[t]{4}{*}{ E_I } & Control & 151 & 1.42 & 0.254 & & $\mathrm{E}$ & & \\
\hline & Business process analyst & 72 & 1.38 & 0.267 & 0.288 & & $\mathrm{E}$ & \\
\hline & IS project manager & 61 & 1.34 & 0.273 & 0.053 & & $\mathrm{E}$ & \\
\hline & IS consultant & 40 & 1.40 & 0.261 & 0.757 & & $\mathrm{E}$ & \\
\hline \multirow[t]{4}{*}{ S_N } & Control & 151 & 1.39 & 0.166 & & $\mathrm{~S}$ & & \\
\hline & Business process analyst & 72 & 1.36 & 0.153 & 0.271 & & $\mathrm{~S}$ & \\
\hline & IS project manager & 61 & 1.35 & 0.143 & 0.106 & & $\mathrm{~S}$ & \\
\hline & IS consultant & 40 & 1.32 & 0.177 & 0.026 & & $\mathrm{~S}$ & \\
\hline \multirow[t]{4}{*}{ T_F } & Control & 151 & 1.46 & 0.180 & & $\mathrm{~T}$ & & \\
\hline & Business process analyst & 72 & 1.43 & 0.175 & 0.393 & & $\mathrm{~T}$ & \\
\hline & IS project manager & 61 & 1.47 & 0.172 & 0.495 & & $\mathrm{~T}$ & \\
\hline & IS consultant & 40 & 1.52 & 0.188 & 0.044 & & $F$ & Table 4. \\
\hline \multirow[t]{4}{*}{ J_P } & Control & 151 & 1.35 & 0.154 & & $\mathrm{~J}$ & & Average values of the \\
\hline & Business process analyst & 72 & 1.30 & 0.142 & 0.010 & & $\mathrm{~J}$ & control group and \\
\hline & IS project manager & 61 & 1.28 & 0.138 & 0.003 & & J & treatment groups (with \\
\hline & IS consultant & 40 & 1.28 & 0.120 & 0.003 & & $\mathrm{~J}$ & significant differences) \\
\hline
\end{tabular}

process analyst, along with significant differences in two personality traits for the IS consultant profession (one less compared to all participants) and three personality traits for the IS project manager profession.

We show that participants for the IS consultant faked-good for the traits S_N towards sensing and for J_P towards judging. For the IS project manager profession, participants faked-good towards extraversion for the trait E_I, towards sensing for S_N and towards judging for J_P. For the data scientist profession, participants faked-good towards sensing for the S_N trait. For the business process analyst profession, participants faked-good towards judging for the J_P trait. Regardless of the profession, participants did not fake-good for the T_F trait. Based on the results, we also conclude that the participant first and foremost faked-good on the J_P trait towards judging. 
Figure 1.

Falsifying personality traits (no significant differences)

Figure 2.

Falsifying personality traits (with significant differences)

\section{Table 5.}

Average values of the T_F control group and treatment groups with higher interest for the selected profession (no significant differences)

\begin{tabular}{|c|c|c|c|c|}
\hline \multirow[b]{2}{*}{ Control group } & \multicolumn{4}{|c|}{ MBTI } \\
\hline & $\begin{array}{c}E \\
(1.42)\end{array}$ & $\begin{array}{l}\text { S } \\
(1.39)\end{array}$ & $\begin{array}{c}T \\
(1.46)\end{array}$ & $\underset{(1.35)}{J}$ \\
\hline $\begin{array}{l}\text { IS security specialist } \\
\text { (sample) }\end{array}$ & $\begin{array}{c}E \\
(1.48)\end{array}$ & $\begin{array}{c}\mathrm{S} \\
(1.31)\end{array}$ & $\begin{array}{c}\mathrm{T} \\
(1.38)\end{array}$ & $\underset{(1.32)}{J}$ \\
\hline $\begin{array}{l}\text { IS security specialist } \\
\text { (proposed trait) }\end{array}$ & $\begin{array}{c}\text { । } \\
(>1.5)\end{array}$ & $\underset{(<1.5)}{\mathrm{S}}$ & \multirow[t]{2}{*}{$\begin{array}{c}\mathrm{T} \\
(<1.5)\end{array}$} & $\underset{(<1.5)}{J}$ \\
\hline $\begin{array}{l}\text { Data scientist } \\
\text { (sample) }\end{array}$ & $\begin{array}{c}E \\
(1.44)\end{array}$ & $\begin{array}{c}\mathrm{S} \\
(1.35)\end{array}$ & & $\underset{(1.34)}{J}$ \\
\hline $\begin{array}{l}\text { Data scientist } \\
\text { (proposed trait) }\end{array}$ & $\begin{array}{c}1 \\
(>1.5)\end{array}$ & $\underset{(>1.5)}{N}$ & $\begin{array}{c}\mathrm{T} \\
(<1.5)\end{array}$ & $\begin{array}{c}P \\
(>1.5)\end{array}$ \\
\hline $\begin{array}{l}\text { IS marketing specialist } \\
\text { (sample) }\end{array}$ & $\begin{array}{c}E \\
(1.39)\end{array}$ & $\begin{array}{c}\mathrm{S} \\
(1.38)\end{array}$ & $\begin{array}{c}\mathrm{T} \\
(1.48)\end{array}$ & $\begin{array}{l}J \\
(1.37)\end{array}$ \\
\hline $\begin{array}{l}\text { IS marketing specialist } \\
\text { (proposed trait) }\end{array}$ & $\underset{(<1.5)}{E}$ & $\underset{(>1.5)}{N}$ & $\begin{array}{c}\mathrm{T} \\
(<1.5)\end{array}$ & $\begin{array}{c}P \\
(>1.5)\end{array}$ \\
\hline
\end{tabular}

\begin{tabular}{|c|c|c|c|c|}
\hline \multirow{3}{*}{$\begin{array}{l}\text { Control group } \\
\text { Business process } \\
\text { analyst (sample) }\end{array}$} & \multicolumn{4}{|c|}{ MBTI } \\
\hline & $\begin{array}{c}E \\
(1.42)\end{array}$ & $\begin{array}{c}\mathrm{S} \\
(1.39)\end{array}$ & $\begin{array}{c}\mathrm{T} \\
(1.46)\end{array}$ & $\underset{(1.35)}{J}$ \\
\hline & $\begin{array}{c}E \\
(1.38)\end{array}$ & $\begin{array}{c}S \\
(1.36)\end{array}$ & $\begin{array}{c}\top \\
(1.43)\end{array}$ & $\underset{(1.30)}{J}$ \\
\hline $\begin{array}{l}\text { Business process } \\
\text { analyst (proposed trait) }\end{array}$ & $\begin{array}{c}1 \\
(>1.5)\end{array}$ & $\underset{(>1.5)}{N}$ & $\begin{array}{c}\mathrm{T} \\
(<1.5)\end{array}$ & $\underset{(<1.5)}{J}$ \\
\hline $\begin{array}{l}\text { IS project manager } \\
\text { (sample) }\end{array}$ & $\begin{array}{c}E \\
(1.34)\end{array}$ & $\begin{array}{c}\mathrm{S} \\
(1.35)\end{array}$ & $\begin{array}{c}T \\
(1.47)\end{array}$ & $\underset{(1.28)}{J}$ \\
\hline $\begin{array}{l}\text { IS project manager } \\
\text { (proposed trait) }\end{array}$ & $\underset{(<1.5)}{E}$ & $\underset{(>1.5)}{N}$ & $\begin{array}{c}T \\
(<1.5)\end{array}$ & $\underset{(<1.5)}{J}$ \\
\hline $\begin{array}{l}\text { IS consultant } \\
\text { (sample) }\end{array}$ & $\begin{array}{c}E \\
(1.40)\end{array}$ & $\begin{array}{c}\mathrm{S} \\
(1.32)\end{array}$ & $\begin{array}{c}F \\
(1.52)\end{array}$ & $\stackrel{J}{J}$ \\
\hline $\begin{array}{l}\text { IS consultant } \\
\text { (proposed trait) }\end{array}$ & $\underset{(<1.5)}{E}$ & $\underset{(>1.5)}{N}$ & $\underset{(>1.5)}{F}$ & $\underset{(>1.5)}{P}$ \\
\hline
\end{tabular}

Note(s): *Significant at $p<0.05$

Personality traits (MBTI)

\begin{tabular}{llllll} 
Variable Profession & $N$ & Mean & Std. dev. & Sig. & Control Selected profession \\
\hline
\end{tabular}

\begin{tabular}{|c|c|c|c|c|c|c|}
\hline E_I & Control & 151 & 1.42 & 0.254 & & $\mathrm{E}$ \\
\hline & IS security specialist & 12 & 1.55 & 0.309 & 0.084 & \\
\hline & IS marketing specialist & 39 & 1.38 & 0.258 & 0.403 & \\
\hline S_N & Control & 151 & 1.39 & 0.166 & & $\mathrm{~S}$ \\
\hline & IS security specialist & 12 & 1.34 & 0.157 & 0.337 & \\
\hline & IS marketing specialist & 39 & 1.39 & 0.168 & 0.977 & \\
\hline T_F & Control & 151 & 1.46 & 0.180 & & $\mathrm{~T}$ \\
\hline & IS security specialist & 12 & 1.42 & 0.185 & 0.518 & \\
\hline & IS marketing specialist & 39 & 1.48 & 0.183 & 0.399 & \\
\hline J_P & Control & 151 & 1.35 & 0.154 & & $\mathrm{~J}$ \\
\hline & IS security specialist & 12 & 1.34 & 0.138 & 0.842 & \\
\hline & IS marketing specialist & 39 & 1.37 & 0.164 & 0.607 & \\
\hline
\end{tabular}




\begin{tabular}{|c|c|c|c|c|c|c|c|c|}
\hline \multirow[b]{2}{*}{ Variable } & \multirow[b]{2}{*}{ Profession } & \multirow[b]{2}{*}{$N$} & \multirow[b]{2}{*}{ Mean } & \multirow[b]{2}{*}{ Std. dev. } & \multirow[b]{2}{*}{ Sig. } & \multicolumn{2}{|c|}{ Personality traits (MBTI) } & \multirow{2}{*}{$\begin{array}{l}\text { Personality in } \\
\text { IS professions }\end{array}$} \\
\hline & & & & & & Control & Selected profession & \\
\hline \multirow[t]{5}{*}{ E_I } & Control & 151 & 1.42 & 0.254 & & $\mathrm{E}$ & & \\
\hline & Business process analyst & 59 & 1.36 & 0.262 & 0.137 & & $\mathrm{E}$ & \\
\hline & IS project manager & 48 & 1.30 & 0.261 & 0.008 & & $\mathrm{E}$ & \\
\hline & Data scientist & 37 & 1.43 & 0.301 & 0.804 & & $\mathrm{E}$ & \\
\hline & IS consultant & 25 & 1.37 & 0.226 & 0.363 & & $\mathrm{E}$ & 63 \\
\hline \multirow[t]{5}{*}{ S_N } & Control & 151 & 1.39 & 0.166 & & $\mathrm{~S}$ & & \\
\hline & Business process analyst & 59 & 1.38 & 0.155 & 0.736 & & $\mathrm{~S}$ & \\
\hline & IS project manager & 48 & 1.33 & 0.122 & 0.035 & & $\mathrm{~S}$ & \\
\hline & Data scientist & 37 & 1.33 & 0.161 & 0.050 & & $\mathrm{~S}$ & \\
\hline & IS consultant & 25 & 1.30 & 0.149 & 0.027 & & $\mathrm{~S}$ & \\
\hline \multirow[t]{5}{*}{ T_F } & Control & 151 & 1.46 & 0.180 & & $\mathrm{~T}$ & & \\
\hline & Business process analyst & 59 & 1.45 & 0.170 & 0.751 & & $\mathrm{~T}$ & \\
\hline & IS project manager & 48 & 1.46 & 0.177 & 0.932 & & $\mathrm{~T}$ & \\
\hline & Data scientist & 37 & 1.44 & 0.197 & 0.754 & & $\mathrm{~T}$ & Table 6. \\
\hline & IS consultant & 25 & 1.49 & 0.191 & 0.440 & & $\mathrm{~T}$ & Average values for the \\
\hline \multirow{5}{*}{ J_P } & Control & 151 & 1.35 & 0.154 & & $\mathrm{~J}$ & & control group and \\
\hline & Business process analyst & 59 & 1.29 & 0.145 & 0.009 & & $\mathrm{~J}$ & treatment groups with \\
\hline & IS project manager & 48 & 1.26 & 0.132 & 0.000 & & $\mathrm{~J}$ & higher interest for the \\
\hline & Data scientist & 37 & 1.34 & 0.153 & 0.591 & & $\mathrm{~J}$ & selected profession \\
\hline & IS consultant & 25 & 1.29 & 0.105 & 0.014 & & J & (significant differences) \\
\hline
\end{tabular}

We also analysed whether gender was an important factor. We found no statistically significant differences in any of the analysed traits in all treatment groups except for two differences, one in IS project manager treatment group and one in IS marketing specialist treatment group. Both differences were also just large enough to cause a change in personality trait (from " $T$ " to "F"). However, both values did not represent a deviation towards the proposed personality trait for the selected profession. Thus, it is more likely that these values represent the characteristics of the gender (feeling versus thinking) rather than faking the answers during the test. The control group shows that male participants were more thinking-oriented, while females were more feeling-oriented.

\section{Discussion}

\subsection{Discussion of findings}

In addition to the specific abilities and skills to successfully perform a certain type of profession, employees also need an appropriate personality type. Thus, a classification system must define archetypal IS professions and the corresponding personality traits for each profession. Such a classification system can benefit employers hiring new employees in a specific field (Barrick et al., 2001). Hence, we identified the archetypal IS professions with the proposed personality traits.

Some studies show that candidates often try to mislead personality traits tests to increase employment opportunities (Dalen et al., 2001; Martin et al., 2002; Rees and Metcalfe, 2003). Thus, to determine how much candidates can fake-good on a personality test to get closer to the desired personality trait, we conducted an experiment on 452 students in an IS-oriented class. Participants were presented with different IS professions with corresponding MBTI personality types. Based on a parametric $t$-test for independent samples, we analysed how much they adjusted their responses to match the targeted personality traits.

The key question is how much participants adjusted their answers towards the proposed personality traits of a chosen profession. Figure 3 summarises the experiment's findings. The 
ITP

35,8

64

red arrows indicate how answers were adjusted to better reflect the personality traits required for a chosen profession. In these cases, participants differed from the control group and actually adjusted their answers towards the chosen profession. As a result, we identify a deviation from true personality traits. The yellow circles indicate differences that do not go towards an individual profession but in the opposite direction. In these cases, we cannot conclude that participants tailored their true personality traits towards a chosen profession. In Figure 3, we separated professions where we identified a significant difference in at least one personality trait and professions where there were no significant differences in all personality traits.

The experiment showed no statistically significant differences in any of the traits for IS security specialist, data scientist or IS marketing specialist. However, for business process analyst, IS project manager, data scientist and IS consultant, the experiment showed statistically significant differences in at least one trait. In these three professions, participants mostly adjusted their answers towards the desired personality trait (judging), most likely to present themselves as people who make quick decisions - a desirable personality trait in the eyes of potential IS employers. Most statistically significant differences appeared for the IS consultant profession. However, not all adjustments were towards the desired personality trait for the selected IS profession.

\subsection{Theoretical implications}

We performed a thorough literature review and classified archetypal IS professions with MBTI-related personality traits that, according to the literature, positively affect employees' performance. We indicated that while individuals' classification in a specific type may be unreliable (Pittenger, 2005), the numerical values can reliably predict candidates' personalities.

The importance of analysing personalities and suitability of the MBTI personality test for software engineers has already been emphasised (Varona et al., 2012), highlighting the complexity of constantly evolving software development processes and the interplay of skills needed to perform these activities with personality types. The same is relevant for the whole IS field, and thus, our study contributes by presenting proposed personality types for each archetypal IS profession. Despite some criticism of the MBTI personality test suggesting it has poor predictive validity and low reliability (Boyle, 1995) and that the error variance can commonly cause classification errors (Hunsley et al., 2003), we found its strong reliability but only when interpreted properly.

Figure 3.

Adjusting responses towards the proposed (ideal) personality trait for a selected IS profession
Without sig. differences

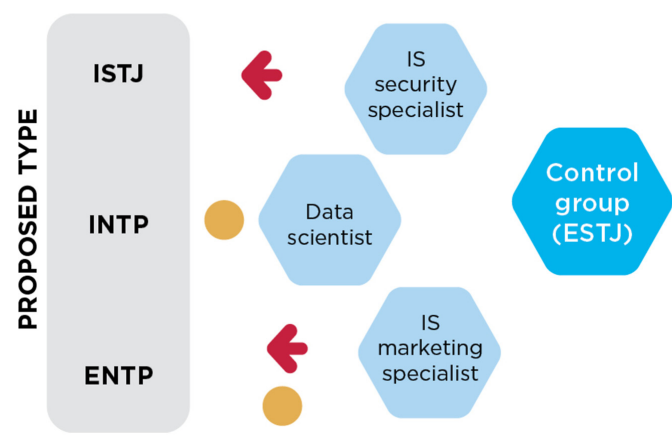

With sig. differences

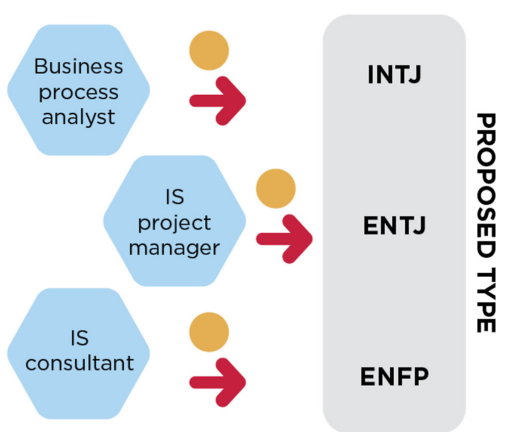


Our paper also contributes to personality-job fit by showing it is possible to operationalise the theory to a particular field and to identify archetype jobs and suitable personalities. The candidates' personalities can then also be reliably measured. Many papers have explored the personalities in IS professions (Cruz et al.,2015), but they have either focussed on a general the IT profession (Lounsbury et al., 2007) or they researched personality types in association with specific IS profession, for example IS developers (Lesiuk et al., 2009), engineers (Varona et al., 2012), software developers (Wynekoop and Walz, 2000) or IT project managers (Cohen et al., 2013). We show how the theory can be used for sub-professions within a certain field.

\subsection{Practical implications}

The results can be generalised to the population of young professionals entering the job market (Compeau et al., 2012). The proposed classification will help employers look for appropriate personality types when selecting the most suitable personnel for a certain archetypal profession. This is important because pre-hire implications of fit have been overlooked in the literature although it is both conceptually interesting and useful in a practical sense for organisations recruiting employees (Ehrhart, 2006). Further, the career types in Table 1 can be used for guiding the career development of the candidates motivated to work in IS professions. Next, as personality types and traits are persistent in time, individuals can recognise their types and more significant traits and learn how to exploit them to compensate for the ones that are not as significant (Wheeler et al., 2004).

Furthermore, the paper shows personality tests are useful indicators of personality types for hiring processes, which allows for further studies and experiments in this area. Findings also indicate that further research of personality tests in IS professions would be meaningful, especially considering our study's limitations. In addition to IS, our study could help in other professions. The paper also demonstrates the usefulness of personality tests in measuring candidates' (and employees') personality types to help them successfully perform their work.

For some professions, the respondents differed from the control group and adjusted their answers towards personality traits that fit the chosen profession. Thus, we conclude that it is possible to fake-good on personality traits to a certain extent. However, some professions do not show personality traits being tailored. Given the above, personality tests are a good indicator, and even participants who are interested in the profession cannot significantly adjust the answers. Nonetheless, decision makers should be extremely cautious. They should consider numerical values instead of blindly trusting the letter-oriented personality trait. Thus, while the difference between 1.49 and 1.51 changes, the identified letter for a particular trait, such a difference in these two candidates' types, may not be as significant as it appears when only checking the personality type. Hence, it is advisable to carefully observe the numerical values (mean) for specific characteristics and compare the results to understand the differences in personality traits amongst candidates.

\subsection{Limitations and suggested future research}

Our research has some limitations to consider. First, identifying personality types for individual IS professions could be more rigorously prepared and further validated via, for example, a Delphi study. That would enable a wider agreement on the archetypal jobs within IS.

Next, although personality type is an essential factor for job performance (Abubakre et al., 2020), it is only one of several indicators for job suitability, thus relying solely on the personality type is not recommended (Tracey et al., 2007). For individuals who are suitable for the IS field, the approach presented in this paper can point them towards the best-fitted IS profession, thus applying the tests could also help show the suitability of people for work in the IS profession in general. However, this approach cannot fully predict actual work 
ITP

35,8

66

performance, which is not influenced solely by the candidate's personality but also by the complex interplay of the personality and organisational culture in a specific organisation (Viswesvaran and Ones, 2000). This could be investigated within the frame of the personality-organisation fit theory.

The MBTI test we used is based on Jung's theory of personality, which has had its validity questioned (Stromberg and Caswell, 2015). Besides, the MBTI questionnaire contains dichotomous questions; therefore, individuals must choose one possibility even if none of the options perfectly describes their behaviour. When re-answering the same questionnaire, respondents were sometimes classified into a different personality type than in the initial test (Grant, 2013), which happens because respondents answered one or two questions differently (Burger, 2004). Thus, experts should assess the use of an MBTI test in groups with proven inconsistencies (Michael, 2003; The Myers and Briggs Foundation, 2019).

Our study used students from one business school as the subjects. Although it is a suitable population for our purpose, not all participants may have a high motivation to fake-good in the tests. Performing the experiment with subjects from different backgrounds or in the organisation of the potential employer would offer further confirmation of our findings.

In addition to the MBTI personality test, it would also be interesting to use other personality tests (e.g. the Big Five) and compare the results. It would be meaningful to use the proposed approach in a real situation with candidates applying for specific IS professions in a specific organisation. Such an approach would enable studying the personality-organisation fit. It would also be useful to survey employees in IS professions to analyse whether their personalities reflect findings from the literature. Additionally, future research could focus on how a personality match affects employee skill development, performance and retention (Kappelman et al., 2020). It would also be helpful to perform the experiment in a real environment and then observe how well candidates with a certain personality trait perform in a certain profession.

\section{Conclusion}

In IS professions, there is a concern that people with inappropriate skills and personality types will enter the job market due to the lucrative career possibilities. Employers can prevent such behaviour using personality tests to find candidates who match the desired characteristics and types for a specific profession. We argued that persistent IS professions exist that are a good match for a certain personality. Based on a theoretical overview, we presented archetypal IS professions with a description of the desired personal characteristics and personality traits. Next, we examined the MBTI test's reliability for the selected IS professions via an experiment in which we observed how much participants attuned their answers and thus faked-good on the personality tests to match the desired IS personality type. We found MBTI tests to be a reliable and trustworthy indicator of candidates' personalities because even participants who were more interested in a specific profession could not significantly adjust a measured personality trait. However, caution is necessary because interpreting an MBTI test can only give a reasonable result when selecting an employee for particular IS job. Accordingly, decision makers should not focus on the final four personality trait letters but rather on the numerical values that provide more accurate information about an individual's personality trait.

\section{References}

Aasheim, C.L., Williams, S. and Butler, E.S. (2009), "Knowledge and skill requirements for IT graduates", Journal of Computer Information Systems, Vol. 49 No. 3, pp. 48-53, doi: 10.1080/ 08874417.2009.11645323. 
Aasheim, C., Shropshire, J., Li, L. and Kadlec, C. (2012), "Knowledge and skill requirements for entrylevel IT workers: a longitudinal study", Journal of Information Systems Education, Vol. 23 No. 2, pp. 193-204.

Abubakre, M., Zhou, Y. and Zhou, Z. (2020), "The impact of information technology culture and personal innovativeness in information technology on digital entrepreneurship success", Information Technology and People, Vol. ahead-of-print No. ahead-of-print, doi: 10.1108/ITP-012020-0002.

Aken, A., Litecky, C., Ahmad, A. and Nelson, J. (2009), "Mining for computing jobs", IEEE Software, Vol. 27 No. 1, pp. 78-85, doi: 10.1109/MS.2009.150.

Baller, S., Dutta, S. and Lanvin, B. (2016), Global Information Technology Report 2016, Ouranos, Geneva.

Barari, M., Ross, M., Thaichon, S. and Surachartkumtonkun, J. (2020), “A meta-analysis of customer engagement behaviour”, International Journal of Consumer Studies, Vol. 45 No. 4, pp. 457-477, doi: $10.1111 /$ ijcs.12609.

Barrick, M.R. (2005), "Yes, personality matters: moving on to more important matters", Human Performance, Vol. 18 No. 4, pp. 359-372, doi: 10.1207/s15327043hup1804_3.

Barrick, M.R., Mount, M.K. and Judge, T.A. (2001), "Personality and performance at the beginning of the new millennium: what do we know and where do we go next?", International Journal of Selection and Assessment, Vol. 9 Nos 1-2, pp. 9-30, doi: 10.1111/1468-2389.00160.

Benešová, A. and Tupa, J. (2017), "Requirements for education and qualification of people in Industry 4.0", Procedia Manufacturing, Vol. 11, pp. 2195-2202, doi: 10.1016/j.promfg.2017.07.366.

Bessen, J. (2019), “Automation and jobs: when technology boosts employment”, Economic Policy, Vol. 34 No. 100, pp. 589-626, doi: 10.1093/epolic/eiaa001.

Blut, M. and Wang, C. (2019), "Technology readiness: a meta-analysis of conceptualisations of the construct and its impact on technology usage", Journal of the Academy of Marketing Science, Vol. 48 No. 4, pp. 1-21, doi: 10.1007/s11747-019-00680-8.

Boyle, G.J. (1995), "Myers-Briggs type indicator (MBTI): some psychometric limitations", Australian Psychologist, Vol. 30 No. 1, pp. 71-74, doi: 10.11821/8857.

Burger, J.M. (2004), Personality, 6th ed., Wadsworth, Belmont, California, CA.

Burton, H., Daugherty, B., Dickins, D. and Schisler, D. (2016), "Dominant personality types in public accounting: selection bias or indoctrinated?”, Accounting Education, Vol. 25 No. 2, pp. 167-184, doi: 10.1080/09639284.2015.1127768.

Cappel, J.J. (2002), "Entry-level IS job skills: a survey of employers", Journal of Computer Information Systems, Vol. 42 No. 2, pp. 76-82, doi: 10.1080/08874417.2002.11647490.

Capraro, R.M. and Capraro, M.M. (2002), "Myers-briggs type indicator score reliability across: studies a meta-analytic reliability generalisation study", Educational and Psychological Measurement, Vol. 62 No. 4, pp. 590-602, doi: 10.1177/0013164402062004004.

Capretz, L.F. and Ahmed, F. (2010), "Why do we need personality diversity in software engineering?", ACM SIGSOFT Software Engineering Notes, Vol. 35 No. 2, pp. 1-11, doi: 10.1145/1734103. 1734111.

Capretz, L.F., Varona, D. and Raza, A. (2015), "Influence of personality types in software tasks choices”, Computers in Human Behavior, Vol. 52, pp. 373-378, doi: 10.1016/j.chb.2015.05.050.

Cattell, H.E.P. and Mead, A.D. (2008), "The sixteen personality factor questionnaire (16PF)", in Boyle, G.J., Matthews, G. and Saklofske, D.H. (Eds), The SAGE Handbook of Personality Theory and Assessment: Volume 2 - Personality Measurement and Testing, Sage Publications, pp. 135-159, doi: 10.4135/9781849200479.n7.

Cheney, P.H., Hale, D.P. and Kasper, G.M. (1989), "Information systems professionals: skills for the 1990s", Paper Presented at the Proceedings of the 22nd Annual Hawaii International Conference 
ITP

35,8

68

on Systems Sciences, Hawaii, pp. 331-336, doi: 10.1109/HICSS.1989.48140 (accessed 9 March 2020).

Cohen, Y., Ornoy, H. and Keren, B. (2013), "MBTI personality types of project managers and their success: a field survey”, Project Management Journal, Vol. 44 No. 3, pp. 78-87, doi: 10.1002/ pmj.21338.

Compeau, D., Marcolin, B., Kelley, H. and Higgins, C. (2012), "Research commentary - generalizability of information systems research using student subjects - a reflection on our practices and recommendations for future research", Information Systems Research, Vol. 23 No. 4, pp. 1093-1109, doi: 10.1287/isre.1120.0423.

Cruz, S., da Silva, F.Q. and Capretz, L.F. (2015), "Forty years of research on personality in software engineering: a mapping study", Computers in Human Behavior, Vol. 46, pp. 94-113, doi: 10.1016/ j.chb.2014.12.008.

Da Cunha, A.D. and Greathead, D. (2007), "Does personality matter? An analysis of code-review ability", Communications of the ACM, Vol. 50 No. 5, pp. 109-112.

Dalen, L.H., Stanton, N.A. and Roberts, A.D. (2001), "Faking personality questionnaires in personnel selection”, Journal of Management Development, Vol. 20 No. 8, pp. 729-741, doi: 10.1108/ 02621710110401428.

DaSilva, C.M. and Trkman, P. (2014), "Business model: what it is and what it is not", Long Range Planning, Vol. 47 No. 6, pp. 379-389, doi: 10.1016/j.lrp.2013.08.004.

Davenport, T.H. and Patil, D.J. (2012), "Data scientist", Harvard Business Review, Vol. 90 No. 5, pp. 70-76.

De Mauro, A., Greco, M., Grimaldi, M. and Ritala, P. (2018), "Human resources for big data professions: a systematic classification of job roles and required skill sets", Information Processing and Management, Vol. 54 No. 5, pp. 807-817, doi: 10.1016/j.ipm.2017.05.004.

Denning, P.J. (2001), “The profession of IT: who are we?”, Communications of the ACM, Vol. 44 No. 2, pp. 15-19.

Devaraj, S., Easley, R.F. and Crant, J.M. (2008), "Research note-how does personality matter? Relating the five-factor model to technology acceptance and use", Information Systems Research, Vol. 19 No. 1, pp. 93-105, doi: 10.1287/isre.1070.0153.

Eberhard, B., Podio, M., Alonso, A.P., Radovica, E., Avotina, L., Peiseniece, L., Caamaño Sendon, M., Gonzales Lozano, A. and Solé-Pla, J. (2017), "Smart work: the transformation of the labour market due to the fourth industrial revolution (I4.0)", International Journal of Business and Economic Sciences Applied Research, Vol. 10 No. 3, pp. 47-66.

Ehrhart, K.H. (2006), "Job characteristic beliefs and personality as antecedents of subjective personjob fit”, Journal of Business and Psychology, Vol. 21 No. 2, pp. 193-226, doi: 10.1007/s10869-0069025-6.

Erdogan, B. and Bauer, T.N. (2005), "Enhancing career benefits of employee proactive personality: the role of fit with jobs and organisations", Personnel Psychology, Vol. 58 No. 4, pp. 859-891, doi: 10. 1111/j.1744-6570.2005.00772.x.

Erjavec, J., Popovič, A. and Trkman, P. (2019), "The effect of personality traits and knowledge on the quality of decisions in supply chains", Economic Research, Vol. 1, pp. 2269-2292, doi: 10.1080/ 1331677X.2019.1642788.

Flynn, W.C. and Philbin, G. (2014), "Behind the help desk: career, salary and training expectations", Issues in Information Systems, Vol. 15 No. 2, pp. 285-292.

Furnham, A. (1996), "The big five versus the big four: the relationship between the Myers-Briggs Type Indicator (MBTI) and NEO-PI five factor model of personality", Personality and Individual Differences, Vol. 21 No. 2, pp. 303-307, doi: 10.1016/0191-8869(96)00033-5.

Furnham, A. (2017), "Myers-Briggs type indicator (MBTI)", in Zeigler-Hill, V. and Shackelford, T. (Eds), Encyclopedia of Personality and Individual Differences, Springer, Cham, doi: 10.1007/978-3319-28099-8_50-1 (accessed 21 June 2020). 
Garg, P. and Rastogi, R. (2006), "New model of job design: motivating employees' performance", Journal of Management Development, Vol. 25 No. 6, pp. 572-587, doi: 10.1108/ 02621710610670137.

Gilal, A.R., Omar, M., Jaafar, J., Mohd Sharif, K.I., Mahessar, A.W. and Basri, S. (2017), "Software development team composition: personality types of programmer and complex network", Paper Presented at the Proceedings of the 6th International Conference on Computing and Informatics, ICOCI 2017, Kuala Lumpur, pp. 153-159, available at: http://repo.uum.edu.my/22818/1/ICOCI\% 202017\%20153-159.pdf (accessed 25 July 2021).

Grant, A. (2013), "Goodbye to MBTI, the fad that won't die", available at: https://www. psychologytoday.com/intl/blog/give-and-take/201309/goodbye-mbti-the-fad-won-t-die (accessed 13 May 2020).

Guillemette, M.G. and Paré, G. (2012), "Toward a new theory of the contribution of the IT function in organisations", Mis Quarterly, Vol. 36 No. 2, pp. 529-551, doi: 10.2307/41703466.

Hunsley, J., Lee, C.M. and Wood, J.M. (2003), "Controversial and questionable assessment techniques", in Lilienfeld, S.O., Lynn, S.J. and Lohr, J.M. (Eds), Science and Pseudoscience in Clinical Psychology, Guilford, New York, NY, pp. 39-76.

Hurtz, G.M. and Donovan, J.J. (2000), "Personality and job performance: the big five revisited", Journal of Applied Psychology, Vol. 85 No. 6, p. 869, doi: 10.1037/0021-9010.85.6.869.

Jackson, D. (2010), "An international profile of industry-relevant competencies and skill gaps in modern graduates", International Journal of Management Education, Vol. 8 No. 3, pp. 29-58, doi: 10.3794/ijme.83.288.

Jia, L., Hall, D., Yan, Z., Liu, J. and Byrd, T. (2018), "The impact of relationship between IT staff and users on employee outcomes of IT users", Information Technology and People, Vol. 31 No. 5, pp. 986-1007, doi: 10.1108/ITP-03-2017-0075.

Kappelman, L., Johnson, V., Torres, R., Maurer, C. and McLean, E. (2019), "A study of information systems issues, practices, and leadership in Europe", European Journal of Information Systems, Vol. 28 No. 1, pp. 26-42, doi: 10.1080/0960085X.2018.1497929.

Kappelman, L., McLean, E., Johnson, V., Torres, R., Maurer, C., Snyder, M., Kim, K. and Guerra, K. (2020), "2020 Comprehensive report: results and observations from the SIM IT Trends Study", available at: https://trends.simnet.org/trends-study-archive (accessed 13 January 2021).

Katic, I., Ivanisevic, A., Grubic-Nesic, L. and Penezic, N. (2018), "Effects of sociodemographic characteristics and personality praits on career development", The International Journal of Aging and Human Development, Vol. 87 No. 2, pp. 201-216, doi: 10.1177/0091415017743008.

Kennedy, R.B. and Kennedy, D.A. (2004), "Using the myers-briggs type indicator ${ }^{\circledR}$ in career counselling", Journal of Employment Counseling, Vol. 41 No. 1, pp. 38-43.

Kim, Y., Hsu, J. and Stern, M. (2006), “An update on the IS/IT skills gap”, Journal of Information Systems Education, Vol. 17 No. 4, p. 395.

Kitch, P. and Yasnoff, W.A. (2003), "Managing IT personnel and projects", in O'Carroll, P.W., Ripp, L.H., Yasnoff, W.A., Ward, M.E. and Martin, E.L. (Eds), Public Health Informatics and Information Systems, Springer, New York, NY, pp. 159-178.

Koong, K.S., Liu, L.C. and Liu, X. (2002), "A study of the demand for information technology professionals in selected internet job portals", Journal of Information Systems Education, Vol. 13 No. 1, p. 4.

Kriegsman, M. and Barletta, R. (1993), "Building a case-based help desk application”, IEEE Expert, Vol. 8 No. 6, pp. 18-26, doi: 10.1109/64.248349.

Kruck, S.E., Sendall, P., Ceccucci, W., Peslak, A. and Hunsinger, S. (2014), "Does personality play a role in computer information systems performance?”, Issues in Information Systems, Vol. 15 No. 2, p. 383. 
ITP

35,8

Le, H., Oh, I.S., Robbins, S.B., Ilies, R., Holland, E. and Westrick, P. (2011), "Too much of a good thing: curvilinear relationships between personality traits and job performance", Journal of Applied Psychology, Vol. 96 No. 1, pp. 113-133, doi: 10.1037/a0021016.

Lee, C.K. and Han, H.J. (2008), "Analysis of skills requirement for entry-level programmer/analysts in Fortune 500 corporations", Journal of Information Systems Education, Vol. 19 No. 1, p. 17.

Lesiuk, T., Pons, A. and Polak, P. (2009), "Personality, mood and music listening of computer information systems developers: implications for quality-of-work", Information Resources Management Journal, Vol. 22 No. 2, pp. 83-97, doi: 10.4018/irmj.2009040105.

Litecky, C., Aken, A., Prabhakar, B. and Arnett, K. (2009), "Skills in the MIS job market", Paper Presented at the AMCIS 2009 Proceedings, p. 255, available at: http://aisel.aisnet.org/amcis2009/ 255 (accessed 9 March 2020).

Livingood, R.A. (2003), Predicting the Success of Potential Information Technology Professionals by Correlation to the Myers-Briggs Type Indicator, Doctoral dissertation, Capella University, Minneapolis, Minnesota.

Lounsbury, J.W., Moffitt, L., Gibson, L.W., Drost, A.W. and Stevens, M. (2007), "An investigation of personality traits in relation to job and career satisfaction of information technology professionals", Journal of Information Technology, Vol. 22 No. 2, pp. 174-183, doi: 10.1057/ palgrave.jit.2000094.

Lounsbury, J.W., Studham, R.S., Steel, R.P., Gibson, L.W. and Drost, A.W. (2009), "Holland's vocational theory and personality traits of information technology professionals", in Dwivedi, Y.K., Lal, B., Williams, M.D., Schneberger, S.L. and Wade, M. (Eds), Handbook of Research on Contemporary Theoretical Models in Information Systems, IGI Global, pp. 529-543, available at: http://doi:10. 4018/978-1-60566-659-4.ch030.

Mahar, D., Cologon, J. and Duck, J. (1995), "Response strategies when faking personality questionnaires in a vocational selection setting", Personality and Individual Differences, Vol. 18 No. 5, pp. 605-609, doi: 10.1016/0191-8869(94)00200-C.

Mahar, D., Coburn, B., Griffin, N., Hemeter, F., Potappel, C., Turton, M. and Mulgrew, K. (2006), "Stereotyping as a response strategy when faking personality questionnaires", Personality and Individual Differences, Vol. 40 No. 7, pp. 1375-1386, doi: 10.1016/j.paid.2005.11.018.

Maier, C. (2012), "Personality within information systems research: a literature analysis", Paper Presented at the ECIS 2012 Proceedings, available at: https://aisel.aisnet.org/ecis2012/101 (accessed 29 April 2020).

Malik, G. and Venkatraman, A. (2017), "The great divide: skill gap between the employer's expectations and skills possessed by employees", Industrial and Commercial Training, Vol. 49 No. 4, pp. 175-182, doi: 10.1108/ICT-11-2016-0071.

Manfreda, A. and Indihar Štemberger, M. (2019), "Establishing a partnership between top and IT managers: a necessity in an era of digital transformation", Information Technology and People, Vol. 32 No. 4, pp. 948-972, doi: 10.1108/ITP-01-2017-0001.

Marcella, R. and Middleton, I. (1996), "The role of the help desk in the strategic management of information systems", OCLC Systems and Services: International Digital Library Perspectives, Vol. 12 No. 4, pp. 4-19, doi: 10.1108/10650759610153993.

Martin, B.A., Bowen, C.C. and Hunt, S.T. (2002), "How effective are people at faking on personality questionnaires?", Personality and Individual Differences, Vol. 32 No. 2, pp. 247-256, doi: 10.1016/ S0191-8869(01)00021-6.

Mendes, F.F., Mendes, E. and Salleh, N. (2019), "The relationship between personality and decisionmaking: a Systematic literature review", Information and Software Technology, Vol. 111, pp. 50-71, doi: 10.1016/j.infsof.2019.03.010.

Michael, J. (2003), "Using the Myers-Briggs type indicator as a tool for leadership development? Apply with caution", Journal of Leadership and Organizational Studies, Vol. 10 No. 1, pp. 68-81, doi: 10. 1177/107179190301000106. 
Moreno, A.M., Sanchez-Segura, M.I., Medina-Dominguez, F. and Carvajal, L. (2012), "Balancing software engineering education and industrial needs", Journal of Systems and Software, Vol. 85 No. 7, pp. 1607-1620, doi: 10.1016/j.jss.2012.01.060.

Morgeson, F.P., Campion, M.A., Dipboye, R.L., Hollenbeck, J.R., Murphy, K. and Schmitt, N. (2007a), "Reconsidering the use of personality tests in personnel selection contexts", Personnel Psychology, Vol. 60 No. 3, pp. 683-729, doi: 10.1111/j.1744-6570.2007.00089.x.

Morgeson, F.P., Campion, M.A., Dipboye, R.L., Hollenbeck, J.R., Murphy, K. and Schmitt, N. (2007b), "Are we getting fooled again? Coming to terms with limitations in the use of personality tests for personnel selection”, Personnel Psychology, Vol. 60 No. 4, pp. 1029-1049, doi: 10.1111/j.17446570.2007.00100.x.

Mroczek, D.K. and Spiro, A. III (2003), "Modeling intraindividual change in personality traits: findings from the Normative Aging Study", The Journals of Gerontology Series B: Psychological Sciences and Social Sciences, Vol. 58 No. 3, pp. 153-165, doi: 10.1093/geronb/58.3.P153.

Müller, O., Schmiedel, T., Gorbacheva, E. and Vom Brocke, J. (2016), “Towards a typology of business process management professionals: identifying patterns of competences through latent semantic analysis", Enterprise Information Systems, Vol. 10 No. 1, pp. 50-80, doi: 10.1080/ 17517575.2014.923514.

Noll, C.L. and Wilkins, M. (2002), "Critical skills of IS professionals: a model for curriculum development", Journal of Information Technology Education, Vol. 1 No. 3, pp. 143-155.

Nunamaker, J.F., Couger, J.D. and Davis, G.B. (1982), "Information systems curriculum recommendations for the 80's: undergraduate and graduate programs-A report of the ACM curriculum committee on information systems", Communications of the ACM, Vol. 25 No. 11, pp. $781-805$, doi: $10.1145 / 358690.358698$.

Persaud, A. (2020), "Key competencies for big data analytics professions: a multimethod study", Information Technology and People, Vol. 34 No. 1, pp. 178-203, doi: 10.1108/ITP-06-2019-0290.

Pflügler, C., Wiesche, M., Becker, N. and Krcmar, H. (2018), "Strategies for retaining key IT professionals", MIS Quarterly Executive, Vol. 17 No. 4, pp. 297-314.

Pittenger, D.J. (2005), "Cautionary comments regarding the Myers-Briggs type indicator", Consulting Psychology Journal: Practice and Research, Vol. 57 No. 3, pp. 210-221.

Rae, D. (2005), "Mid-career entrepreneurial learning", Education + Training, Vol. 47 Nos 8-9, pp. 562-574, doi: 10.1108/00400910510633116.

Rainie, L. and Anderson, J. (2017), “The future of jobs and jobs training”, available at: https://www. pewresearch.org/internet/2017/05/03/the-future-of-jobs-and-jobs-training/ (accessed 14 March 2020).

Rees, C.J. and Metcalfe, B. (2003), "The faking of personality questionnaire results: who's kidding whom?", Journal of Managerial Psychology, Vol. 18 No. 2, pp. 156-165, doi: 10.1108/ 02683940310465045 .

Research and Markets (2019), "IT job family classification system - version 2.2", available at: https:// www.researchandmarkets.com/reports/4778765/it-job-family-classification-system-version-2-2 (accessed 15 February 2020).

Richards, T., Yellen, R., Kappelman, L. and Guynes, S. (1998), "Information systems manager's perceptions of IS job skills”, Journal of Computer Information Systems, Vol. 38 No. 3, pp. 53-57, doi: 10.1080/08874417.1998.11647340.

Roberts, B.W. and Mroczek, D. (2008), "Personality trait change in adulthood", Current Directions in Psychological Science, Vol. 17 No. 1, pp. 31-35, doi: 10.1111/j.1467-8721.2008.00543.x.

Rushton, J.P. and Irwing, P. (2009), “A general factor of personality in the comrey personality scales, the Minnesota multiphasic personality inventory-2, and the multicultural personality questionnaire", Personality and Individual Differences, Vol. 46 No. 4, pp. 437-442, doi: 10.1016/ j.paid.2008.11.015. 
ITP

35,8

Rushton, S., Morgan, J. and Richard, M. (2007), "Teacher's Myers-Briggs personality profiles: identifying effective teacher personality traits", Teaching and Teacher Education, Vol. 23 No. 4, pp. 432-441, doi: 10.1016/j.tate.2006.12.011.

Sackett, P.R. and Walmsley, P.T. (2014), "Which personality attributes are most important in the workplace?”, Perspectives on Psychological Science, Vol. 9 No. 5, pp. 538-551, doi: 10.1177/ 1745691614543972 .

Sadler, M. (2015), "Why is the MBTI widely used?", available at: https://www.researchgate.net/post/ Why_is_the_MBTI_widely_used2/55364343cf57d7db418b463b/citation/download (accessed 23 June 2020).

Salleh, N., Mendes, E. and Grundy, J. (2014), "Investigating the effects of personality traits on pair programming in a higher education setting through a family of experiments", Empirical Software Engineering, Vol. 19 No. 3, pp. 714-752, doi: 10.1007/s10664-012-9238-4.

Seetharaman, P. (2020), "Business models shifts: impact of Covid-19", International Journal of Information Management, Vol. 54, 102173, doi: 10.1016/j.ijinfomgt.2020.102173.

Sekiguchi, T. and Huber, V.L. (2011), "The use of person-organisation fit and person-job fit information in making selection decisions", Organizational Behavior and Human Decision Processes, Vol. 116 No. 2, pp. 203-216, doi: 10.1016/j.obhdp.2011.04.001.

Sorauren, I.F. (2000), "Non-monetary incentives: do people work only for money?", Business Ethics Quarterly, Vol. 10 No. 4, pp. 925-944, doi: 10.2307/3857840.

Stein, R. and Swan, A.B. (2019), "Evaluating the validity of Myers-Briggs Type Indicator theory: a teaching tool and window into intuitive psychology", Social and Personality Psychology Compass, Vol. 13 No. 2, e12434, doi: 10.1111/spc3.12434.

Stromberg, J. and Caswell, E. (2015), "Why the Myers-Briggs test is totally meaningless", available at: https://www.vox.com/2014/7/15/5881947/myers-briggs-personality-test-meaningless (accessed 11 April 2020).

Summers, T., Lyytinen, K.J., Lingham, T. and Pierce, E.A. (2013), "How hackers think: a study of cybersecurity experts and their mental models", Paper Presented at the Third Annual International Conference on Engaged Management Scholarship, Atlanta, Georgia, 19 - 22 September, doi: 10.2139/ssrn.2326634 (accessed 25 October 2020).

Swope, K.J., Cadigan, J., Schmitt, P.M. and Shupp, R. (2008), "Personality preferences in laboratory economics experiments", The Journal of Socio-Economics, Vol. 37 No. 3, pp. 998-1009, doi: 10. 1016/j.socec.2006.12.065.

The Myers \& Briggs Foundation (2019), "Reliability and validity", available at: https://www. myersbriggs.org/my-mbti-personality-type/mbti-basics/reliability-and-validity.htm (accessed 23 April 2019).

Tischler, L. (1994), “The MBTI factor structure”, Journal of Psychological Type, Vol. 31, pp. 24-31.

Todd, P.A., McKeen, J.D. and Gallupe, R.B. (1995), "The evolution of IS job skills: a content analysis of IS job advertisements from 1970 to 1990", MIS Quarterly, Vol. 19 No. 1, pp. 1-27, doi: 10.2307/ 249709.

Tomat, L. and Trkman, P. (2019), "Digital transformation-the hype and conceptual changes", Economic and Business Review, Vol. 21 No. 3, pp. 351-370, doi: 10.15458/ebr.90.

Tracey, J.B., Sturman, M.C. and Tews, M.J. (2007), "Ability versus personality: factors that predict employee job performance", Cornell Hotel and Restaurant Administration Quarterly, Vol. 48 No. 3, pp. 313-322, doi: 10.1177/0010880407302048.

Trkman, M., Mendling, J., Trkman, P. and Krisper, M. (2019), "Impact of the conceptual model's representation format on identifying and understanding user stories", Information and Software Technology, Vol. 116, 106169, doi: 10.1016/j.infsof.2019.08.001.

Van der Aalst, W.M.P. (2014), "Data Scientist: the engineer of the future", in Mertins, K., Bénaben, F., Poler, R. and Bourrières, J.P. (Eds), Enterprise Interoperability VI. Proceedings of the I-ESA Conferences, Springer, Cham, Vol. 7, pp. 13-26, doi: 10.1007/978-3-319-04948-9_2. 
Van Slyke, C., Kittner, M. and Cheney, P. (1998), "Skill requirements for entry-level IS graduates: a report from industry", Journal of Information Systems Education, Vol. 9 No. 3, p. 7.

Varona, D., Capretz, L.F. and Piñero, Y. (2011), "Personality types of Cuban software developers", Global Journal of Engineering Education, Vol. 13 No. 2, pp. 77-81.

Varona, D., Capretz, L.F., Piñero, Y. and Raza, A. (2012), "Evolution of software engineers' personality profile", ACM SIGSOFT Software Engineering Notes, Vol. 37 No. 1, pp. 1-5.

Viswesvaran, C. and Ones, D.S. (2000), "Perspectives on models of job performance", International Journal of Selection and Assessment, Vol. 8 No. 4, pp. 216-226, doi: 10.1111/1468-2389.00151.

Personality in IS professions

Warhurst, C., Lockyer, C. and Dutton, E. (2006), "IT jobs: opportunities for all?", New Technology, Work and Employment, Vol. 21 No. 1, pp. 75-88, doi: 10.1111/j.1468-005X.2006.00164.x.

Wheeler, P.R., Hunton, J.E. and Bryant, S.M. (2004), "Accounting information systems research opportunities using personality type theory and the Myers-Briggs type indicator", Journal of Information Systems, Vol. 18 No. 1, pp. 1-19.

Williamson, J.M., Lounsbury, J.W. and Han, L.D. (2013), "Key personality traits of engineers for innovation and technology development", Journal of Engineering and Technology Management, Vol. 30 No. 2, pp. 157-168.

World Economic Forum (2020), “The future of jobs report 2020", available at: https://www.weforum. org/reports/the-future-of-jobs-report-2020 (accessed 8 November 2020).

Wynekoop, J.L. and Walz, D.B. (2000), "Investigating traits of top performing software developers", Information Technology and People, Vol. 13 No. 2, pp. 186-195, doi: 10.1108/09593840010377626.

Yagmur, A.A. and Jaideep, M. (2018), "Gender based investigation of stereotypical barriers in management information systems profession”, Advances in Management, Vol. 11 No. 4, pp. 1-8.

Young, D. (1996), "The relative importance of technical and interpersonal skills for new information systems personnel”, Journal of Computer Information Systems, Vol. 36 No. 4, pp. 66-71, doi: 10. 1080/08874417.1996.11647229.

Zimmerman, R.D. (2008), "Understanding the impact of personality traits on individuals' turnover decisions: a meta-analytic path model”, Personnel Psychology, Vol. 61 No. 2, pp. 309-348, doi: 10. 1111/j.1744-6570.2008.00115.

\section{Corresponding author}

Anton Manfreda can be contacted at: anton.manfreda@ef.uni-lj.si

For instructions on how to order reprints of this article, please visit our website:

www.emeraldgrouppublishing.com/licensing/reprints.htm

Or contact us for further details: permissions@emeraldinsight.com 